\section{Areas of industrial damages in upper Silesian industrial region versus recultivation or revitalization?}

\author{
Małgorzata Falencka-Jabłońska \\ Department of Forest Ecology, Forest Research Institute, Poland
}

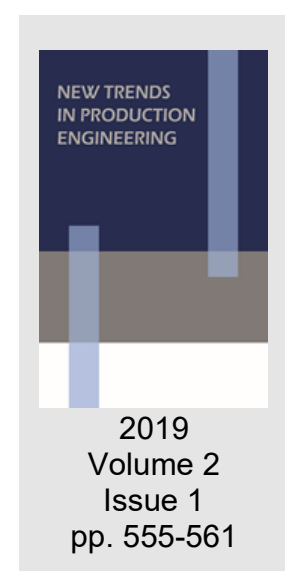

Date of submission to the Editor: 05/2019

Date of acceptance by the Editor: 08/2019

\title{
INTRODUCTION
}

Changes in natural environment and often irreversible changes in structure and functioning of ecosystems are a result of systematic and long-lasting process of human pressure. Especially visible are negative effects of industrial influence on environment observed for over last 200 years. Dynamic economic and civilization development caused that industrial emission and its accumulation influenced on increasing pace of environment degradation, not only on areas directly surrounding industrial plants (Falencka-Jabłońska 2006, 2013, 2015, Falencka-Jabłońska, Sobczyk 2017).

The degree of environment contamination was a reflection of amount of emitted contamination. Data from the half of the 80 's of $20^{\text {th }}$ century showed, that at that time, in our country, every year over 5 million tons of gas contamination had reached the atmosphere. According to data from Central Statistical Office at that time, responsible for that were around 7 thousand industrial plants. Among them, 1.100 most oppressive were responsible for $90 \%$ of global emission (Rudzki, 1985).

At the turn of 19th and 20th century, polish industry has emitted around 3 million tons of $\mathrm{SO}_{2}$ which gave Poland leading place among all Europe's countries in this shameful list. Due to dominant direction of western winds additionally over our territory pushed were annually from Germany and Czech Republic jointly around 1.5 million $\mathrm{SO}_{2}$ (Falencka-Jabłońska, 2013).

A region of our country on which special impact had industrial pressure is Upper Silesian Industrial Region. Industry development and long-term and large scale extraction of raw materials influenced on extremely strong contamination of natural environment and its permanent degradation. Especially visible these processes are in the region of Tarnowskie Góry and Miasteczko Śląskie. That is why many-years research and analysis on this area in the 70's of last century by Department of Plant Ecology and Environmental Conservation of Forest Research Institute are of significant meaning. Those results were a base for theory of industriogeneous desert and industrioclimax by Janusz Wolak, a head 
of the Department. This author indicated that with systematic growth of industrial contamination accumulation it becomes decisive factor that determines degradation of ecosystems. At the same time, the author defined, that "industriogeneous changes are a driving force for succession of new vegetation adjusted to such conditions. The final stage of this process, at the assumption of permanent concentration of air contamination, will be a stage of industrioclimax with relative balance and a degree of permanence" (Wolak 1969,1970). The results of conducted research indicated that after exceeding the level of tolerance for forest biocenoses and their components, in the center of concentration of toxic substances a specific desert occurs. As the distance from the center of emission increases visible are grasslands. In further distance observed can be bushes and trees of deformed forms and miniaturized sizes which are creating thickets. A continuation of these multi-aspect and interdisciplinary research has found its reflection in the synthesis of 40-years analysis and complex evaluations included in monograph (Falencka-Jabłońska, 2015).

One of important industrial plants of discussed area that has particularly strong impact on natural environment is existing for over half of the century Huta Cynku "Miasteczko Śląskie". Presently it is a leading producer, because its share in global production balance is $40 \%$ of zinc and $50 \%$ of lead and alloy. This plant, for the sake of environment, bases its activity on modern technologies and areas exposed to strong pressure of harmful industrial emission. Especially so called industriogeneous desert are being recultivated. The subject of this article are results of presently conducted research which purpose is land use planning and revitalization of areas on which impact had Huta Cynku "Miasteczko Śląskie" emissions.

\section{METHODS AND RESEARCH MATERIAL}

In June 2017 collected were 200 samples of soil from three zones exposed to emission from two levels $(0-20 \mathrm{~cm}$ and $21-40 \mathrm{~cm})$. Soil analysis was made by accredited Laboratory of Natural Environment Chemistry of Forest Research Institute. Defined was the $\mathrm{pH}$ and content of heavy metals: lead, cadmium, zinc, copper, manganese, chromium and nickel.

Obtained data were compared with acceptable values included in Minister of Environment Regulation on standard of soil quality and standards of soil quality. It defines standards for soil quality with including their function for three groups of soils: A, B and C.

On the base of obtained results, established were 3 testing grounds, each of 0.5 ha representing zones of: low, medium and extreme contamination. Two of them ( $A$ and $B$ ) were located on forest areas and the third one, on so called industriogeneous desert, next to Huta Cynku's sinter plant. On all testing grounds a cultivation was made, and additionally on ground $\mathrm{C}$ a sweetening was made.

In order to protect future planting from the game, all testing grounds were fenced with a forest mesh. Selected were appropriate set of species for planting using 
instructions included in "Guidelines for selection of trees and bush species for protective tree standings in ecological non-forest zone and renewal in 3rd zone of strong threats in lowland conditions" (Hawryś 1986,1990, Józefaciuk 1988). Selected species were common birch - Betula pentula Ruth., black alder - Alnus glutinosa Gaertn., Norway maple - Acer platanoides L., field maple - Acer campestre L., European mountain ash - Sorbus auquparia L. From recommended in those conditions bush species selected were Siberian dogwood - Sorbus auquparia L.and European red elder - Sambucus racemosa L.

Whole homogenous planting material (2 year old seedlings) originated from Świerklaniec Forest District which guaranteed high quality.

On each of three testing grounds plantings were made in October, 2017. Planting density was $1 \times 1 \mathrm{~m}$. Each seedling had substrate from forest nursery in order to ensure "proper start" in new, hard conditions. On three testing grounds of joint area of 1.5 ha planted were all together 6550 seedlings.

In 2018 triple inventory and estimation of seedlings number on all three testing grounds was made (the first decade of May, the third decade of June and midAugust).

Performed were at the time detailed analysis of all plantings on testing grounds by registering survival rate, condition, disease symptoms which occurred with particular seedlings etc.

\section{RESEARCH RESULTS}

\section{Soil analysis and the degree of its contamination}

This evaluation was concentrated mainly on contamination by heavy metals, especially lead and zinc.

Obtained results indicate, that in extreme zone the content of lead in level 0-20 $\mathrm{cm}$ ranged in samples from $486 \mathrm{mg} / \mathrm{kg}$ to $5358 \mathrm{mg} / \mathrm{kg}$. This means 9-times crossing the norm. In level $21-40 \mathrm{~cm}$ it ranged from $21 \mathrm{mg} / \mathrm{kg}$ to $5197 \mathrm{mg} / \mathrm{kg}$ what means 8.5-times crossing the norms. In the zone of medium contamination on industrial areas the content of lead in level $0-20 \mathrm{~cm}$ ranged from $128 \mathrm{mg} / \mathrm{kg}$ to $5658 \mathrm{mg} / \mathrm{kg}$ what indicated 9-times crossing the norms. On the other hand in level $20-40 \mathrm{~cm}$ the content of this element did not exceed the acceptable norms. In the zone of low contamination of forest areas the content of lead in level 0-20 $\mathrm{cm}$ ranged from $88 \mathrm{mg} / \mathrm{kg}$ to $5638 \mathrm{mg} / \mathrm{kg}$ what means 7-times crossing the norms. However in level $21-40 \mathrm{~cm}$ no exceeding the acceptable norms was noted - Fig. 1, 2.

Obtained results of analysis indicate, that the content of zinc in level 0-20 cm of soil in extreme zone ranged from $982 \mathrm{mg} / \mathrm{kg}$ to $8742 \mathrm{mg} / \mathrm{kg}$ what means 8.5 times crossing the norms. On the other hand in level $21-40 \mathrm{~cm}$ it amounted from $208 \mathrm{mg} / \mathrm{kg}$ to $4770 \mathrm{mg} / \mathrm{kg}$ what indicated on 4.5-times crossing the norms. In the area of low contamination on forest areas the content of zinc in level 0-20 cm ranged from $78 \mathrm{mg} / \mathrm{kg}$ to $908 \mathrm{mg} / \mathrm{kg}$ what means 1.4-times crossing the norms. In the other hand in level $21-40 \mathrm{~cm}$ the content of this element did not exceed acceptable norms - Fig. 1, 2. 


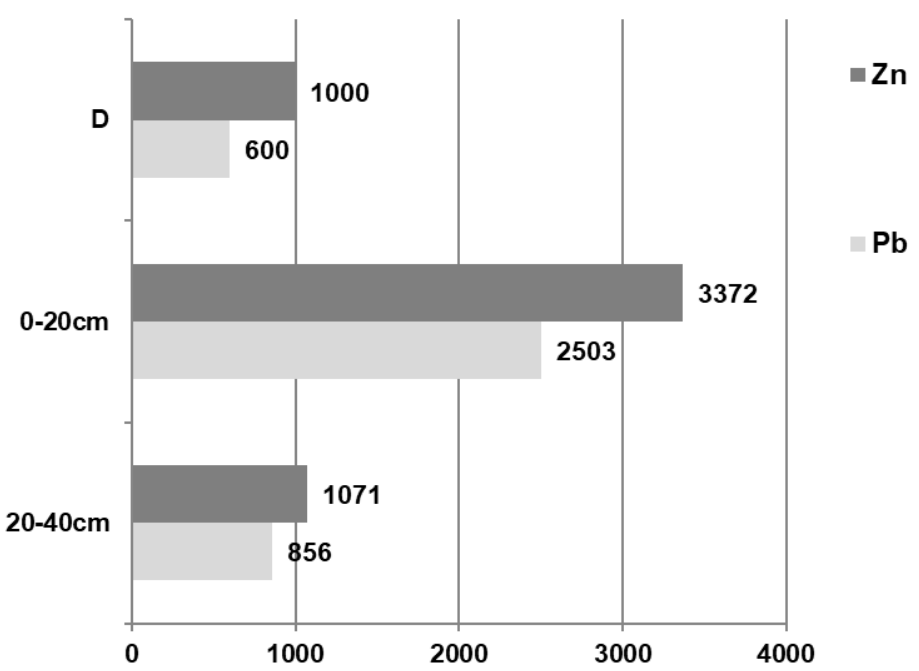

Fig. 1 The content of $\mathrm{Pb}$ and $\mathrm{Zn}(\mathrm{mg} / \mathrm{kg})$ in soils of extreme zone (D-acceptable values)

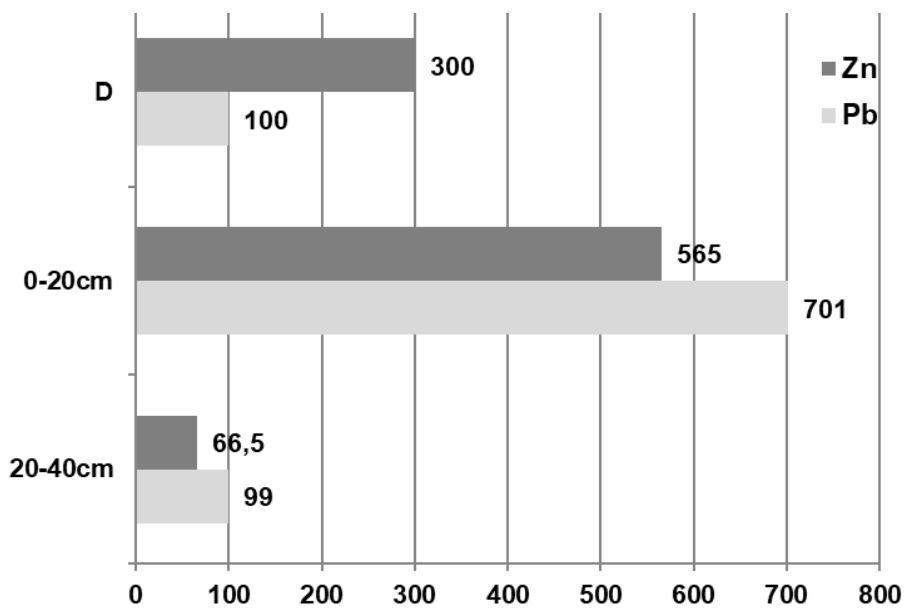

Fig. 2 The content of $\mathrm{Pb}$ and $\mathrm{Zn}(\mathrm{mg} / \mathrm{kg})$ in soils of low contamination

On the base of evaluation of soil contamination a localization of testing grounds was established (Fig. 3).
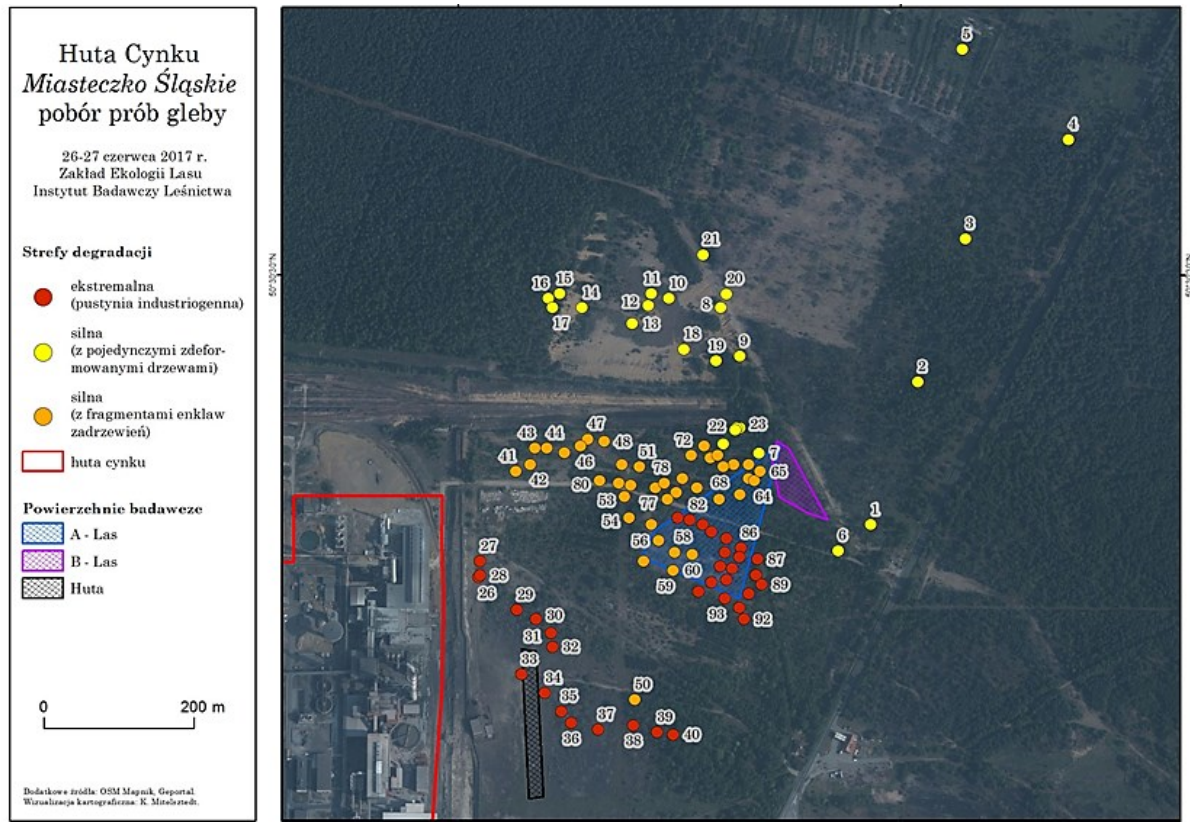

Fig. 3 Distribution of experimental plots of forest Research Institute (IBL) in particular risk zones) 


\section{Inventory and estimation of plantings on testing grounds}

Results of first May inventory showed that mortality of seedlings on forest testing ground A amounted $22.8 \%$, on forest testing ground $B-36 \%$ and on testing ground $\mathrm{C}$ which was industriogeneous desert $-38.2 \%$.

Following June evaluation of plantings' condition showed that:

On forest testing ground A stated were only 7 birches with necrosis symptoms what stands for $1 \%$ of this species number, and 26 seedlings of black alder characterized with necrosis symptoms what constitutes $8.7 \%$ of general number of this species. Therefore 33 seedlings from 1510 had died. That decided of mortality on level of $2.2 \%$. Therefore mortality has decreased over 10 -times compared to May, 2018.

On forest testing ground B stated were 35 birches which showed necrosis features, what constitutes $3.5 \%$ of number of seedlings of this species. Also 230 seedlings of black alder characterized with necrosis symptoms what constitutes $23 \%$ of all seedlings from this species. In general 267 seedlings out of 2940 had died what influenced on mortality on level of $9.1 \%$.

Therefore mortality has decreased almost 4-times compared to May, 2018.On both forest testing grounds proper growth and good condition of European red elder and birches.

On testing ground $\mathbf{C}$ - the industriogeneous desert noted was presence of 94 birches with necrosis symptoms what constitutes $6.7 \%$ of plantings of this species and 140 seedlings of alder characterized with necrosis symptoms what stands for $28 \%$ of their general number of seedlings. In general there were 234 seedlings dead out of their general number 2100, what indicates that the mortality amounted $11.1 \%$.

Therefore the mortality has decreased over 3.4-times compared to May, 2018. Following evaluations of plantings on three testing grounds indicated on diversity of reaction on pressure of industrial emissions by individual species, therefore:

On forest testing ground $\mathbf{A}$ the seedlings were characterized with proper growth. Over $70 \%$ of black alder and birch seedlings stood out with good condition, dense foliage. Only in this time of observation, stated was intensive growth of white dogwood.

On forest testing ground B the highest seedlings of birch has reached height of $1.3 \mathrm{~m}$. Only few showed symptoms of permanent decay. Few maples had necrosis on their leaves. This phenomenon regarded mainly Norway maple. Black alder was characterized with good condition and dense foliage. With few seedlings of European mountain ash noted were in lower parts, burnt, dead leaves. European red elder, especially the highest seedlings had necrosis on their leaves and burnt fruits on the top of the shoots. Just like on testing ground $A$, the white dogwood only in August stood out with intensive growth and good condition.

On testing ground $\mathbf{C}$ the industriogeneous desert under sinter plant of Huta, around $10 \%$ of the tallest birches $(120 \mathrm{~m})$ had burnt leaves on the top and on lower shoots leaves had numerous necroses. At the same time the areas of the testing ground was characterized with turfing by wood small-reed Calamagrostis 
epigejos (L.) Roth, which in some tufts reached $80 \mathrm{~cm}$ height. It should be emphasized that it is an indicator species for low level of ground water. At the same time in 2018 vegetative season when run were research over seedlings on testing grounds stated was (results from automatic meteorological station) following average values of rainfall in following months: April-5.0 mm, May- 66.4 $\mathrm{mm}$, June-39.2mm, July-76.8 mm, August-17.8 mm. September-46.2mm, October-29.2 mm. Therefore jointly average sum of the rainfall in this year's vegetative season amounted only $280.6 \mathrm{~mm}$, registering the conditions of the extreme drought.

\section{RESULTS}

On the base of results of conducted research, evaluations and analysis concluded can be:

- Evaluation and analysis of soil contamination showed significant concentration of heavy metals, especially lead, cadmium and zinc. Their values were significantly higher in level $0-20 \mathrm{~cm}$ than in level $21-40 \mathrm{~cm}$,

- Trees and bush species planted in October, 2017 on designated testing grounds with diversified gradient of soil contamination, in first vegetation season despite exceptionally long-lasting drought and high temperature showed high survivability. It amounted $82 \%$ on industriogeneous desert and (testing ground C) $90-95 \%$ on forest testing grounds (A and B),

- Maples stood out with proper growth and condition among trees. Black alder showed symptoms of necrosis in May, but already in June the mortality of seedlings has been reduced several times,

- The highest seedlings, especially of European mountain ash, birch and European red elder already in August had burnt apical shoots and numerous necroses on leaves,

- Planned introduction of plants - hyperaccumulators of heavy metals, especially on testing ground on industriogeneous desert in future vegetative seasons, will influence positively on condition and growth of seedlings.

\section{REFERENCES}

Falencka-Jabłońska M. 2006. Synteza 30-letnich kompleksowych analiz wpływu Elektrowni „Kozienice” na środowisko leśne w monografii: Ochrona powietrza w teorii i w praktyce (red. Konieczyński J.), tom II: 67-78. Inst. Podst. Inż. Śr., Zabrze.

Falencka-Jabłońska M. (red.) 2013. Zmiany ekosystemów leśnych w zasięgu oddziaływania Elektrowni „Kozienice”-synteza 40-letnich badań interdyscyplinarnych, Prace IBL, Rozprawy i Monografie 20, ss.304.

Falencka-Jabłońska M. (red.) 2015 Wpływ imisji przemysłowych na strukturę lasów i zmiany komponentów środowiska- synteza 40-letnich badań w Górnośląskim Okręgu Przemysłowym Prace IBL, Rozprawy i Monografie 21, ss.157.

Falencka-Jabłońska M. 2018 opracowanie planu i metod zagospodarowania strefy maksymalnej kumulacji imisji przemysłowych w zasięgu oddziaływania Huty Cynku „Miasteczko Śląskie”. Dokumentacja IBL.

Falencka-Jabłońska M., Sobczyk W. 2017 Rozwój zrównoważony a ochrona przyrody Edukacja Technika Informatyka nr.1(19):139-144, Wyd. Uniw. Rzeszowskiego. 
Hawryś Z.,1986. Wytyczne w sprawie doboru gatunków drzew i krzewów do zadrzewień ochronnych w ekologicznej strefie nieleśnej oraz odnowień w III strefie silnych zagrożeń, w warunkach nizinnych. Dokumentacja IBL.

Hawryś Z. 1990. Ustalenie zestawu gatunków drzew i krzewów przydatnych do zalesień obszarów znajdujących się pod wpływem emisji przemysłowych. Dokumentacja IBL.

Józefaciuk W.1988. Próba określenia żywotności wybranych gatunków drzew i krzewów na obszarach znajdujących się pod wpływem imisji przemysłowych Prace IBLnr.666:3-23.

Rudzki K.1985. Czy stać nas na dalsze niszczenie lasów ?. Referat w ramach posiedzenia Rady NOT oraz Stowarzyszenia Inżynierów i Techników Drzewnictwa, grudzień, Warszawa.

Wolak J. 1969 Industrioklimaks nowe pojęcie w teorii sukcesji. Ekologia polska ser. B, $\mathrm{XV}, 1: 41-44$.

Wolak J. 1970. Powstawanie nowych układów ekologicznych pod wpływem emisji przemysłowych, Sylwan 8/9.

\begin{abstract}
.
Areas of industrial damages require elaborating efficient methods of reclamation and revitalization. A region of Poland, where process of degradation is particularly visible is Upper Silesian Industrial Region. Areas in the zone of many-years influence of Huta "Miasteczko Śląskie" are characterized by norm-exceeding concentration of heavy metals. The area in its direct surrounding was defined as industriogeneous desert. In 2017 on three designated testing grounds with diversified degree of contamination (see: map) of joint area of 1.5 ha, planted were jointly 6550 seedlings of chosen species of trees and bushes which were likely to survive in those conditions. In the first vegetative season, despite extremely long-lasting drought and high temperatures, the seedlings showed high survivability. It amounted $82 \%$ on industriogeneous desert (testing ground $\mathrm{C}$ ) and $90-95 \%$ on forest testing grounds ( $\mathrm{A}$ and $\mathrm{B}$ ). Maples stood out among other trees with proper development and condition. The highest seedlings, especially mountain ash, birch and European red elder already in August had burnt top shoots and numerous necroses on leaves. Introduction of plants - hyperaccumulators of heavy metals, especially on industriogeneous desert will influence positively on condition and development of seedlings in future vegetative seasons.
\end{abstract}

Keywords: industriogeneous desert, reclamation of industrial areas, species tolerating contamination by heavy metals 